\title{
Influence of metribuzin on weed density and yield of soybean (Glycine max L.) under rainfed condition of Vidisha district of Madhya Pradesh
}

\author{
P. K. Mishra* and Ghanshyam Jamliya \\ Department of Agronomy, J.N.K.V.V. College of Agriculture, Ganjbasoda, VIDISHA(M.P.) INDIA \\ (Email : mailsonumishra@gmail.com)
}

\begin{abstract}
A field experiment was conducted at College of Agriculture, Ganjbasoda during Kharif season of 2016, in Randomized Block Design with three replications to find out the effect of new formulation of metribuzin on weeds of soybean (Glycine max L.). The population of weeds differed significantly due to weed control treatments. Highest weed control efficiency was recorded with treatment metribuzin 70WG (Triazinone herbicide) @ $0.525 \mathrm{~kg}$ a.i/ha followed by metribuzin 70 WG (Triazinone herbicide) @ 0.385 $\mathrm{kg}$ a.i/ha and metribuzin 70 WG (Triazinone herbicide) @ $0.350 \mathrm{~kg}$ a.i/ha. application of metribuzin $70 \mathrm{WG}$ (Triazinone herbicide) $@ 0.525 \mathrm{~kg}$ a.i $/$ ha produced maximum seed yield followed by metribuzin $70 \mathrm{WG}$ (Triazinone herbicide) @ $0.385 \mathrm{~kg}$ a.i/ha, metribuzin 70 WG (Triazinone herbicide) @ $0.350 \mathrm{~kg}$ a.i/ha.
\end{abstract}

Key Words : Metribuzin, Weed control treatments, Soybean

View Point Article : Mishra, P.K. and Jamliya, Ghanshyam (2018). Influence of metribuzin on weed density and yield of soybean (Glycine max L.) under rainfed condition of Vidisha district of Madhya Pradesh. Internat. J. agric. Sci., 14 (1) : 56-59, DOI:10.15740/HAS/IJAS/ 14.1/56-59.

Article History : Received : 30.10.2017; Revised : 06.11.2017; Accepted : 19.11.2017

\footnotetext{
* Author for correspondence:
} 